\title{
Peripheral plasma androstenedione and testosterone concentrations in bulls before and during puberty
}

\author{
G. Abdel Malak Bedair and M. Thibier*† \\ Laboratoire d'Hormonologie U.N.C.E.I.A., B.P.65, 94700 Maisons-Alfort, France and \\ $\dagger$ Institut National Agronomique Paris-Grignon, 78850 Thiverval-Grignon, France
}

\begin{abstract}
Summary. Peripheral plasma samples were collected from 37 young bulls every other month from 2 to 12 months of age. Androstenedione and testosterone were measured by radioimmunoassays. Androstenedione values increased from 2 to 4 months of age $(525 \pm 296$ (s.d.) pg/ml) and then decreased. Testosterone concentrations increased regularly from 2 months $(0.17 \pm 0.14 \mathrm{ng} / \mathrm{ml})$ to 6 months $(2.79 \pm 1.29 \mathrm{ng} / \mathrm{ml})$ and then remained at levels around $3 \mathrm{ng} / \mathrm{ml}$. Coefficients of correlation between the hormone concentrations were significant only at 6 months and thereafter.
\end{abstract}

\section{Introduction}

Androstenedione has been identified in the bull testis (Lindner \& Mann, 1960) and in spermatic vein blood, but testosterone is likely to be the principal androgenic hormone in this species (Lindner, 1969). Androstenedione is classically considered to be the predominant testicular androgen in many species before sexual maturity (Eik-Nes, 1975). However, the androgenic activity of androstenedione is very low relative to that of testosterone and is probably related to the rapid peripheral conversion of androstenedione to androgenically inactive compounds (Mann, Rowson \& Hay, 1960; Lindner, 1969). Measurements of testosterone and androstenedione in the testes of calves showed that the ratio of androstenedione:testosterone decreased with advancing age and became less than 1 at about 5 to 6 months of age (Lindner \& Man, 1960; Skinner, Mann \& Rowson, 1968; Lindner, 1969).

The mean peripheral concentrations of testosterone in the first year of life has been studied for bulls of beef (Lacroix, Garnier \& Pelletier, 1977) and dairy breeds (Thibier, 1975, 1977) but a detailed study of androstenedione concentrations with age has not been reported. In our preliminary studies, it was found that androstenedione levels were highly variable within individuals as was reported previously for testosterone and 17-hydroxyprogesterone levels (Thibier, 1976) and therefore data from a large number of animals are required to establish if the patterns show significant variations with advancing age.

The aim of the present study was therefore (1) to investigate mean plasma androstenedione concentrations in bulls before and during puberty and (2) to establish whether or not the androstenedione concentrations were correlated with those of testosterone.

\section{Materials and Methods}

Blood samples were collected at the same time of day $(14: 00 \mathrm{~h})$ from the jugular veins of 37 French Friesian bulls at 2, 4, 6, 8 and 10 months of age. Because some were discarded after 10 months for reasons such as insufficient growth rate or poor health problems, only 25 of the bulls

\footnotetext{
* Present address: Dr M. Thibier at Endocrine Laboratory, School of Medicine, P.O. Box 016960, Biscayne Annex, Miami, Florida 33101, U.S.A.
} 
were sampled at 12 months of age. The bulls were brought to the performance test station when they were 8 days old and were kept in similar conditions thereafter. From 10 months of age onwards, semen was collected once weekly (Thibier \& Colchen-Bourlaud, 1972). All the bulls displayed normal libido and had not received any previous hormone treatment. Four males castrated at 3 months of age were also sampled when 12 months old. The blood samples were withdrawn into heparinized evacuated tubes and then were centrifuged at room temperature (about $20^{\circ} \mathrm{C}$ ) immediately after collection $(3000 \mathrm{~g} ; 10 \mathrm{~min})$. The plasma was removed and stored at $-20^{\circ} \mathrm{C}$ until assayed.

Because of some defects, only 29 bulls had all their plasma analysed from 2 to 10 months of age and intra-class coefficients of correlation (Snedecor \& Cochran, 1956) have been calculated from those 29 animals.

Testosterone concentrations were analysed by the radioimmunoassay previously described (Thibier, 1975, 1976). The antiserum was raised in rabbit immunized against testosterone-3-(Ocarboxy)methyloxime-BSA (Fondation de la Recherche en Hormonologie, Paris). The reliability of the method is satisfactory (Thibier, 1976). Interassay precision for duplicate assays was $7.3 \%$ and the limit of sensitivity was $0.03 \mathrm{ng} / \mathrm{ml}$ (Martin, Fouchet \& Thibier, 1976). Androstenedione was also measured by radioimmunoassay (Mondain-Monval, Bonnin \& Scholler, 1979). In brief, the plasma androstenedione was extracted by diethyl ether and then was partly purified by chromatography on a minicolumn (Pasteur pipette $0.5 \times 5 \mathrm{~cm}$ ) of Sephadex LH-20 using benzene/ethanol $(95: 5 \mathrm{v} / \mathrm{v})$. The antiserum was raised against androstenedione-3-(O-carboxy)methyloxime-bovine serum albumin and after dilution (1(10000) $200 \mu \mathrm{l}$ were used in the assay. The mean value of the water blank was less than $5 \mathrm{pg} / \mathrm{ml}(n=30)$ and this value was not subtracted in calculating plasma values. Intra-assay and interassay precision (coefficients of variation) of plasma pools were $7.2 \%(n=10)$ and $10.8 \%(n=15)$ respectively. The limit of detection of the androstenedione assay was calculated as being $20 \mathrm{pg} / \mathrm{ml}$.

Analyses of variance, Student's $t$ tests and intra-class correlations were carried out according to Snedecor \& Cochran (1956).

\section{Results}

The androstenedione and testosterone concentrations obtained are reported in Table 1.

Table 1. Mean \pm s.d. concentrations of androstenedione and testosterone in young bulls at different ages

\begin{tabular}{lccc}
\hline $\begin{array}{c}\text { Age } \\
\text { (months) }\end{array}$ & $\begin{array}{c}\text { No. of } \\
\text { bulls }\end{array}$ & $\begin{array}{c}\text { Androstenedione } \\
(\mathrm{pg} / \mathrm{ml})\end{array}$ & $\begin{array}{c}\text { Testosterone } \\
(\mathrm{ng} / \mathrm{ml})\end{array}$ \\
\hline 2 & 37 & $363 \pm 117$ & $0.17 \pm 0.14$ \\
4 & 36 & $529 \pm 296$ & $0.97 \pm 0.89$ \\
6 & 36 & $209 \pm 104$ & $2 \cdot 79 \pm 1 \cdot 99$ \\
8 & 34 & $127 \pm 51$ & $3.48 \pm 2 \cdot 65$ \\
10 & 34 & $163 \pm 97$ & $2 \cdot 82 \pm 2 \cdot 10$ \\
12 & 25 & $150 \pm 105$ & $2 \cdot 22 \pm 1 \cdot 23$ \\
12 (castrated) & 4 & $38.5 \pm 12 \cdot 5$ & $<0.03$ \\
\hline
\end{tabular}

\section{Androstenedione}

Androstenedione levels were significantly higher $(P<0.05)$ than those of the castrated animals (values between non-detectable and $73 \mathrm{pg} / \mathrm{ml}$ ). Analysis of variance showed significant differences between age periods (Table 2). When comparing two successive age periods it was found that the values were significantly different $(P<0.01)$ between $2,4,6$ and 8 months, but not thereafter (8, 10 and 12 months). The highest mean value was at 4 months of age. Consideration of the 29 bulls for which plasma samples were analysed between 2 and 10 months 
showed that age periods and individual effects on androstenedione concentrations were significant (Table 2). The intra-class correlation coefficient was calculated as $\mathbf{0 . 5 3}$.

\section{Testosterone}

The mean testosterone concentrations increased linearly and significantly from 2 to 6 months of age $(r=+0.64 ; y=1.27+1.29 x ; P<0.01)$, but then they remained at a steady level around $3 \mathrm{ng} / \mathrm{ml}$ until 12 months of age. No between-bulls effects were observed.

\section{Androstenedione: testosterone ratio}

This decreased from 2.11 at 2 months of age to 0.07 at 6 months and then remained between 0.03 and 0.07 . The correlations between androstenedione and testosterone concentrations at each age period were not significant $(P>0.05)$ at 2 and 4 months of age, but were significant $(P<0.01)$ from 6 to 12 months of age.

Table 2. Analysis of variance of plasma androstenedione concentrations in the same 29 bulls between 2 and 10 months of age

\begin{tabular}{lrcccc}
\hline \multicolumn{1}{c}{$\begin{array}{c}\text { Source of } \\
\text { variation }\end{array}$} & d.f. & $\begin{array}{c}\text { Sum of } \\
\text { squares }\end{array}$ & $\begin{array}{c}\text { Mean } \\
\text { square }\end{array}$ & F & $P$ \\
\hline Total & 144 & 6.75 & - & & \\
Between age periods & 4 & 3.22 & 0.81 & 40.5 & $<0.001$ \\
Between bulls & 28 & 0.92 & 0.33 & 16.5 & $<0.001$ \\
Residual & 112 & 2.61 & 0.02 & & \\
\hline
\end{tabular}

\section{Discussion}

Androstenedione mean values were at all periods, including around puberty at about 10 months of age (Attal \& Courot, 1963), significantly higher than those of the castrated animals, confirming that most of this steroid originates from the testis (Lindner, 1969). The pattern of the peripheral plasma concentrations did not show erratic fluctuations with advancing age in contrast to the findings of Rawlings, Hafs \& Swanson (1972). However, the high concentrations at 2 and 4 months and then a decline are in agreement with the results from study of testicular and spermatic vein plasma concentrations (Lindner \& Mann, 1960; Lindner, 1969). Around puberty (8-12 months of age: Attal \& Courot, 1963), the mean levels are about $150 \mathrm{pg} / \mathrm{ml}$ and therefore quite different from those reported by Rawlings et al. (1972) who, however, collected blood at slaughter and it is possible that this way of sampling might not give an exact reflection of physiological status. Moreover, only a limited number of bulls was sampled ( 5 bulls per age). By contrast, the magnitude of the concentrations reported here are in quite good agreement with those reported for young bulls by Mongkonpunya, Hafs, Convey, Tucker \& Oxender (1975), and for cows by Kanchev \& Dobson (1976), although they are a little higher than those found by Peterson, Fairclough \& Smith (1978) in cow plasma at the time of luteolysis and oestrus.

A large variation of the androstenedione concentrations at each age period occurred from one bull to the other, as demonstrated by the large coefficients of variation (around $50 \%$ ). This might be related to the large daily fluctuations reported for other steroids (Thibier, 1976) as well as for androstenedione (P. Chantaraprateep \& $\mathrm{M}$. Thibier, unpublished results). However the intra-class coefficient of correlation was significant $\left(r_{i} \simeq 0.5\right)$, indicating that some bulls had either lower or higher levels at each age period than others.

The testosterone concentrations showed regular increase to 6 months and then steady mean levels which are quite close to the mean levels previously reported around puberty (Thibier, 
1975). This regular increase starts from birth, as shown by sampling of large groups of animals at each period (Thibier, 1977) or of a small number of calves sampled regularly during the first year of life (Lacroix et al., 1977).

The androstenedione:testosterone ratio from peripheral plasma concentrations is similar to that reported by Lindner \& Mann (1960) and Lindner (1969). Although the highest mean androstenedione levels were observed at 4 months, the ratio at this age (well before puberty) was already less than 1, indicating that androstenedione is no longer the quantitatively predominant androgen in peripheral plasma. The fact that testosterone and androstenedione concentrations were not significantly correlated within each age period before 6 months of age suggests that, until this age, peripheral concentrations of these two steroids are independently controlled.

Together with the evidence of significant correlations between testosterone and androstenedione only from 6 months of age onwards, the most striking feature of this study is that the mean androstenedione concentrations were apparently increasing from 2 to 4 months and then decreasing. This pattern appears to be similar to that of $\mathrm{LH}$, as reported by Thibier (1977) for the same plasma samples, i.e. high levels at 2 and 4 months and lower concentrations at 6,8 , 10 and 12 months of age. This LH pattern has been confirmed by Lacroix et al. (1977) in young beef bulls. The relationship between the testosterone concentrations and LH patterns (Thibier, 1977; Lacroix et al., 1977) led to the conclusion that the 4-6 month period corresponds to the onset of the adult type of negative feed-back mechanism. The present study shows that androstenedione levels are high while those of $\mathrm{LH}$ are high, and it is only when the normal testosterone-LH negative feed-back works (i.e. at 6 months and onwards) that the concentrations of testosterone and androstenedione are correlated, suggesting a common control mechanism of secretion.

We thank Mrs N. Jeanguyot for her skilful technical assistance.

\section{References}

Attal, J. \& Courot, M. (1963) Développement testiculaire et établissement de la spermatogénèse chez le taureau. Annls Biol. anim. Biochim. Biophys. 3, 219-241.

Eik-Nes, K.B. (1975) Biosynthesis and secretion of testicular steroids. In Handbook of Physiology, Volume 5, Section 7, Male Reproductive System, Chap. 4, pp. 95-115. Eds D. W. Hamilton \& R. O. Greep. Am. Physiol. Soc., Washington, D.C.

Kanchev, L.N. \& Dobson, H. (1976) Plasma concentration of androstenedione during the bovine oestrous cycle. J. Endocr. 71, 351-354.

Lacroix, A., Garnier, D.H. \& Pelletier, J. (1977) Temporal fluctuations of plasma LH and testosterone in Charolais bull calves during the first year of life. Annls Biol. anim. Biochim. Biophys. 17, 1013-1019.

Lindner, H.R. (1969) The androgenic secretion of the testis in domestic ungulates. In The Gonads, Chap. 20, pp. 615-648. Ed. K. B. McKerns. North-Holland, Amsterdam.

Lindner, H.R. \& Mann, T. (1960) Relationship between the content of androgenic steroids in the testes and the secretory activity of the seminal vesicles in the bull. $J$. Endocr. 21, 341-360.

Mann, T., Rowson, L.E.A. \& Hay, M. (1960) Evaluation of androgenic and gonadotrophic activity in male twin calves by analysis of seminal vesicles and semen. J. Endocr. 21, 361-372.

Martin, B., Fouchet, C. \& Thibier, M. (1976) Steroidprotein interactions in bovine plasma. J. Reprod. Fert. 46, 143-149.

Mondain-Monval, M., Bonnin, M. \& Scholler, R. (1979) Androgens in peripheral blood of red fox ( $V$ ulpes vulpes L) during the reproductive season and anoestrus. J. Steroid Biochem. (in press).
Mongkonpunya, K., Hafs, H.D., Convey, E.M., Tucker, H.A. \& Oxender, W.D. (1975) Serum luteinizing hormone, testosterone and androstenedione in pubertal and prepubertal bulls after gonadotropin releasing hormone. J. Anim. Sci. 40, 682-686.

Peterson, A.J., Fairclough, R.J. \& Smith, J.F. (1978) Radioimmunoassay of androstenedione and testosterone in cow plasma at the time of luteolysis and oestrus. J. Reprod. Fert. 52, 127-129.

Rawlings, N.C., Hafs, H.D. \& Swanson, L.V. (1972) Testicular and blood plasma androgens in Holstein bulls from birth through puberty. J. Anim. Sci. 34, $435-440$.

Skinner, J.D., Mann, T. \& Rowson, L.E.A. (1968) Androstenedione in relation to puberty and growth of the male calf. J. Endocr. 40, 261-262.

Snedecor, G.W. \& Cochran, M.G. (1956) Statistical Methods, 5th edn. Iowa State University Press, Ames.

Thibier, M. (1975) Peripheral plasma testosterone concentrations in bull around puberty. J. Reprod. Fert. 42, 567-569.

Thibier, M. (1976) Diurnal testosterone and $17 \alpha^{-}$ hydroxyprogesterone in peripheral plasma of young post-pubertal bulls. Acta endocr., Copenh. 81, 623634.

Thibier, M. (1977) Contribution à l'étude de la fonction sexuelle du jeune taurillon. Thèse Doctorat d'Etat ès Sciences, Université P. \& M. Curie (Paris VI), 100 pp.

Thibier, M. \& Colchen-Bourlaud, M.A. (1972) Le choix du jeune taurillon sur sa fonction sexuelle. Elevage Insém. 127, 3-43. 